\title{
Electronic Commerce During the Covid-19 Pandemics: A Bibliometric Analysis Approach
}

\section{Baris Batuhan Gecit}

To Link this Article: http://dx.doi.org/10.6007/IJARBSS/v11-i11/11421

DOI:10.6007/IJARBSS/v11-i11/11421

Received: 18 September 2021, Revised: 20 October 2021, Accepted: 30 October 2021

Published Online: 11 November 2021

In-Text Citation: (Gecit, 2021)

To Cite this Article: Gecit, B. B. (2021). Electronic Commerce During the Covid-19 Pandemics: A Bibliometric Analysis Approach. International Journal of Academic Research in Business and Social Sciences, 11(11), 2432-2444.

\section{Copyright: (c) 2021 The Author(s)}

Published by Human Resource Management Academic Research Society (www.hrmars.com)

This article is published under the Creative Commons Attribution (CC BY 4.0) license. Anyone may reproduce, distribute, translate and create derivative works of this article (for both commercial and non0-commercial purposes), subject to full attribution to the original publication and authors. The full terms of this license may be seen at: http://creativecommons.org/licences/by/4.0/legalcode

Vol. 11, No. 11, 2021, Pg. $2434-2444$

Full Terms \& Conditions of access and use can be found at http://hrmars.com/index.php/pages/detail/publication-ethics 


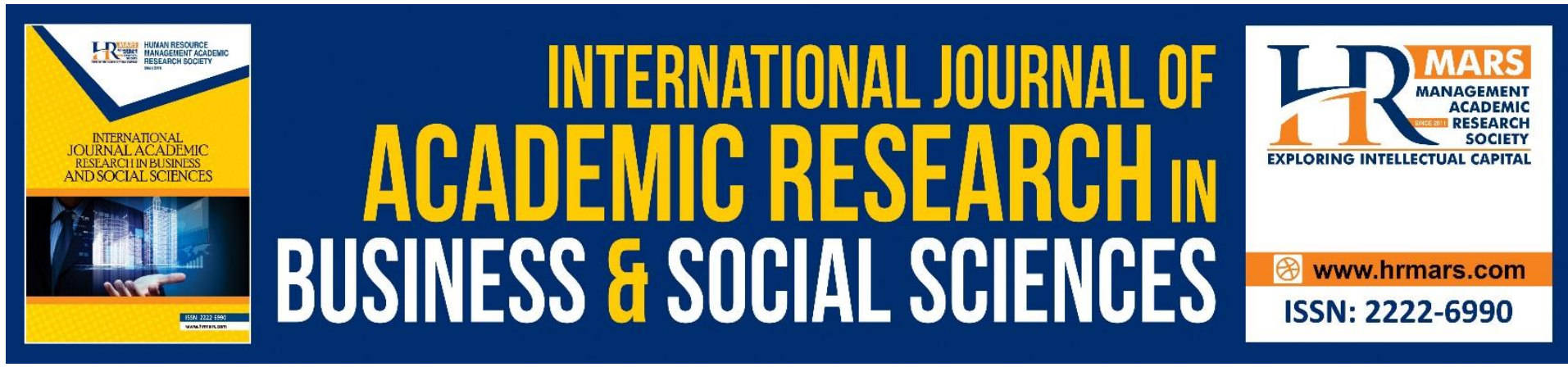

\title{
Electronic Commerce During the Covid-19 Pandemics: A Bibliometric Analysis Approach
}

\author{
Baris Batuhan Gecit \\ Faculty of Economics, Administrative and Social Sciences, Nisantasi University, Istanbul, \\ Turkey. \\ Email: baris.gecit@nisantasi.edu.tr
}

\begin{abstract}
There has been lots of pandemics throughout history and most of them have effected people's live intensively. Covid-19 (Coronavirus) has been among these major pandemics. Worldwide effects of the Covid-19 pandemic has been dramatic in 2020. There have been both effects in terms of lifestyle regarding trade dynamics and economics. Since, trade networks have declined, businesses have been declared bankrupt, employees have gone unemployed, etc. there has been an economic decline. However, one sector that has emerged and converted this crisis to an opportunity has been electronic commerce. Significantly increasing power of digitalization throughout recent years has already been empowering ecommerce. Because it has been the only way to do shopping and buy urgent needs, Covid-19 pandemics have increased e-commerce enormously in 2020.

Accordingly, this article mainly discusses the term of pandemics and how pandemics acted upon e-commerce with the undergoing process of digital penetration. After reviewing these terms in literature section, a bibliometric analysis have been conducted regarding and the found keywords with this analysis have been discussed.
\end{abstract}

Keywords: E-Commerce, Covid-19, Pandemics, Consumer Behaviour

\section{Introduction}

Pandemics have been a major factor affecting people's lives for centuries. The epidemic caused by the coronavirus, known as COVID 19, first appeared in Wuhan, China in December 2019. It has shown an effect all over the world in terms of health, economy, business life, social life, education. World Health Organization (WHO) declared COVID-19 as an epidemic on February 11, 2020 (WHO, 2020). As of August 31, 2021, the new Coronavirus caused $216,303,376$ confirmed cases and 4,498,451 deaths (WHO, 2021).

Pandemics change how people live their daily lives, and the way economics and trade is being applied. Global pandemics have affected business activities and economic growth dramatically either negatively or positevely (Chung, 2015). Covid-19 pandemics have affected the dynamics of economics and there has been a dramatic decline in world economics. Trade systems have collapsed and lots of entrepreneurs have declared bankrupt. But in this process, e-commerce is one of the sectors that is affected positively. 
The Covid-19 pandemics has accelerated the process of shifting from the physical environment to the virtual environment. Since people's avoidance of physical contact, imposing a curfew, places that are closed for a certain period or partially working, physical trade has come to a standstill. Especially the retail sector has been one of the sectors affected mostly by the epidemic due to reasons such as curfews and measures, disruption and slowdown of the supply chain. In parallel with technological developments, the world market has become universal and all kinds of commercial transactions can be done electronically and in a short time. With the transition to the information society, the development of the concept of virtual organization, e-commerce is more common. The rise of e-commerce has come to an unmissable point and e-commerce has bolstered up the potential negative drawbacks of Covid-19. In addition to them, digital penetration has already been empowering e-commerce. In other words, many of the activities we carry out in contact with each other have started to shift to digital environments. Synchronously usage of digital devices and usage of e-commerce have been increasing strikingly for the last 20 years.

Immediately after the corona virus affected the world, many countries took many measures for small businesses to prevent the pandemic situation from growing further. At first, barbers, cafes and entertainment venues was brought in to limit services such as bakery shops. Although small businesses started to be negatively affected by these applications, it is possible to say that the density of businesses providing e-commerce services has increased. In short, at this point, we can say that the corona virus epidemic is an opportunity for ecommerce companies to increase their revenues if they manage their services correctly. Because during this period, most of the people who stayed at their homes started to make purchases such as clothes, furniture and cosmetics, including grocery needs, on the internet in order to protect their families and themselves from the danger of coronavirus.

Shortly, e-commerce gives many oppurtunities to its users such as being practical, making people to reach many products in seconds, more campaigns and discounts benefited, contactless payment opportunity, availability of many product varieties and especially not needing to leave the house. And thanks to its features like these, the rise of e-commerce was inevitable during this pandemic process. With the rise of e-commerce, companies providing e-commerce services continue to rise. It is also possible to say that people mostly turn to online shopping especially during this pandemic process. In other words, people who use ecommerce only for grocery shopping also use it to purchase products such as technology, cosmetics, clothing, decoration. For this reason, with e-commerce, which shows its importance again in the pandemic process, there will be great increases in the revenues of the companies serving in this direction.

Consumers are increasingly flocking to online purchases as a result of the Covid-19 effect; as a result, managers must be proactive in exploring other forms of supply that increase interest in the facilitation of enterprises and consumers (Tran, 2021, 1).

The primary objective of this study is to identify the most relevant keywords related to ecommerce during the Covid-19 era with the perspective of literature from international trade and international marketing disciplines. Accordingly a bibliometric analysis has been conducted and results have been interpreted.

\section{Consumer Trends \& Trade Dynamics During Covid-19}

There have been lots of pandemics and quarantines throughout the history of the World. Covid-19 is among the most disastrous pandemics of history. Unfortunately, relating a 
disaster that causes death of millions of people worldwide to commerce is a sad fact but it has affected the economics and trade dynamics so intensively.

The COVID-19 pandemic has also changed consumer behavior significantly. With the Covid19 pandemic, the compulsory decline of classical trade environments has further led people to electronic commerce. During the Covid-19 pandemic, since there was a period when people went out to the streets less and their tendency to shop from stores decreased (Euronews, 2020), consumers turned to electronic platforms to meet their shopping needs. In quarantine times, people has not been able to purchase both their daily needs and hedonic needs from brick and mortar stores. Some people may tend to shop more from brick and morter stores since they can evaluate products there and thus they can avoid uncertainity (Song et al., 2020).

However, people were constrained to purchase goods from e-commerce websites. In other words, due to the customer preferences and measures taken such as declaring quarantine and isolation, the internet user activity has increased in shopping applications. The increasing trend of online shopping has shown the possibility of further acceleration in the pandemic environment, and it has been inevitable for companies to enter electronic markets (Yükselen, 2020). Thus consumption trends have changed with the emerge of e-commerce (Zhang and Zhao, 2014) and especially with the Covid-19 pandemics.

According to the report of McKinsey\&Company (2021); since January 2020, credit and debit card data indicated a roughly $20 \%$ spike in online spending, and this pandemic-induced ecommerce boom was no fluke. The digital future is unstoppable. In 2019, 92 percent of those who tried internet purchasing became converts, turning emergency preparedness into a necessary habit. Ecommerce has also revolutionized convenience, with classic tactile purchasing experiences like supermarket shopping seeing a significant increase.

There has already been an increase for products like fresh foods at e-commerce platforms (Sun, 2021). Especially for urgent goods such as food, market or medical products such as masks and sanitizers, rapid transit has been crucial throughout the Covid-19 pandemic. There has been a tremendous explosion of demand for direct virus-related products such as hand sanitizer, and the product's prices have seen a huge price increase of $50 \%$ on Amazon.com (Davis \& Toney, 2020).

While negatively affected by the epidemic, online retailers increase their sales volume and customers are gaining. The fact that Covid-19 pandemic has overlapped with the enormous increase of digital penetration accelerated the digitalization of commerce even more. There was already a trend towards digital penetration even before the pandemic. The total amount of world electronic commerce was $\$ 19.3$ Trillion in 2012 . This number has increased to $\$ 27.7$ Trillion in 2016 (World Trade Organization, 2018, 21). A growth of 45.5\% has been observed in the world electronic commerce within a total of four years. According to the Turkish Republic Ministry of Commerce (2020) data, the food and the supermarket sector via ecommerce have shown an increase of $420 \%$ from 2019 to 2020. In Turkey, throughout the first six months of 2020, the e-commerce sector has seen an increase of $64 \%$ (Turkish Republic Ministry of Commerce, 2020, 2).

According to Oberlo (2021); global e-commerce sales was $\$ 3.354$ Trillion in 2019, $\$ 4.280$ Trillion in 2020 and is expected to be $\$ 4.891$ Trillion by the end of 2021. Same upwards momentum is expected to continue in upcoming years. Global e-commerce sales is expected to be $\$ 5.424$ Trillion in 2022, $\$ 5.908$ Trillion in 2023 and $\$ 6.388$ in 2024 . Of course these numbers are approximate estimations but unless something ordinary happens, this upwards momentum is expected to continue (Oberlo, 2021). 
As seen from statistics above share and scale of e-commerce has been increasing year by year which is predicted to continue even more in upcoming years, focus of business activities and marketing strategies for both local and international companies should prioritise e-commerce more if they are operating in a related sector.

\section{Bibliometric Analysis}

Bibliometric analysis is a technique that makes it possible to provide a macroscopic overview of large amounts of academic literature (van Nunen et al., 2018, 248). This analysis allows researchers to conduct an analysis with a systematic approach that could quantitatively analyze scientific publications to identify particular research phenomena (Chen et al., 2017, 1052).

Bibliometric analysis has been used for this study. There are various applications to use bibliometric analysis, and among them, VOSviewer has been used. VOSviewer is a program that allows you to create maps based on network data and then visualize and explore them (van Eck and Waltman, 2021, 3). There are also lots of analytical methods for bibliometric analysis and among them keyword analysis has been conducted.

Keyword analysis has been an important research theme in bibliometrics. The deduction of new valuable bibliometric indicators/approaches through keyword analysis is vital for prompting the further development of this subject area. In this study, the following three bibliometric indicators/approaches were thus derived (Wang and Chai, 2018, 721).

The co-occurrences method works with keywords of the selected articles. Articles including words of "E-Commerce" and "Covid-19" in their title or abstracts have been selected from Scopus document search system. 345 articles from Scopus have been selected for the analysis.

These documents have been uploaded to VOSviewer application and a keyword bibliometric analysis have been conducted. Even they have the same meaning, both "E-Commerce" and "Electronic Commerce" terms have been included to analysis as some articles tend to use "ECommerce" term while some tend to use "Electronic Commerce" term.

Clusters of keywords, their total links, total links strengths and occurrences have been given in Table 1. below. 
Table 1. Keyword Results

\begin{tabular}{|c|c|c|c|c|}
\hline Cluster & Keyword & Links & $\begin{array}{l}\text { Total Link } \\
\text { Strength }\end{array}$ & Occurrences \\
\hline 1 & Electronic Commerce & 28 & 74 & 32 \\
\hline 1 & Sustainability & 22 & 52 & 27 \\
\hline 1 & Sustainable Development & 13 & 25 & 12 \\
\hline 1 & Supply Chain Management & 12 & 18 & 10 \\
\hline 1 & E-Learning & 3 & 5 & 10 \\
\hline 1 & Business Development & 15 & 21 & 7 \\
\hline 1 & Artificial Intelligence & 11 & 12 & 7 \\
\hline 1 & Innovation & 19 & 28 & 9 \\
\hline 1 & Technology & 9 & 12 & 8 \\
\hline 1 & Technology Adoptation & 15 & 20 & 8 \\
\hline 1 & Digital Transformation & 8 & 8 & 6 \\
\hline 2 & E-Commerce & 24 & 60 & 34 \\
\hline 2 & Covid-19 & 26 & 121 & 82 \\
\hline 2 & Pandemic & 16 & 41 & 16 \\
\hline 2 & Trust & 5 & 12 & 10 \\
\hline 2 & Technology Acceptance Model & 4 & 6 & 7 \\
\hline 2 & Online Shopping & 13 & 20 & 10 \\
\hline 2 & Service Quality & 8 & 9 & 7 \\
\hline 2 & Customer Satisfaction & 6 & 8 & 9 \\
\hline 3 & Coronavirus & 19 & 62 & 22 \\
\hline 3 & Viral Disease & 20 & 74 & 18 \\
\hline 3 & Social Media & 13 & 25 & 13 \\
\hline 3 & Epidemic & 14 & 41 & 9 \\
\hline 3 & China & 18 & 41 & 14 \\
\hline 4 & Consumption Behavior & 17 & 51 & 14 \\
\hline 4 & Perception & 10 & 17 & 10 \\
\hline 4 & Consumer Behavior & 10 & 13 & 7 \\
\hline 4 & United States & 15 & 27 & 7 \\
\hline
\end{tabular}

According to Table 1. there are total of 30 items, 4 clusters, 209 links and total of 470 link strength used in this analysis.

Keyword analysis of "E-Commerce" and "Covid-19" terms have been given in the Figure 1. below. 


\section{Figure 1. Keyword Network}

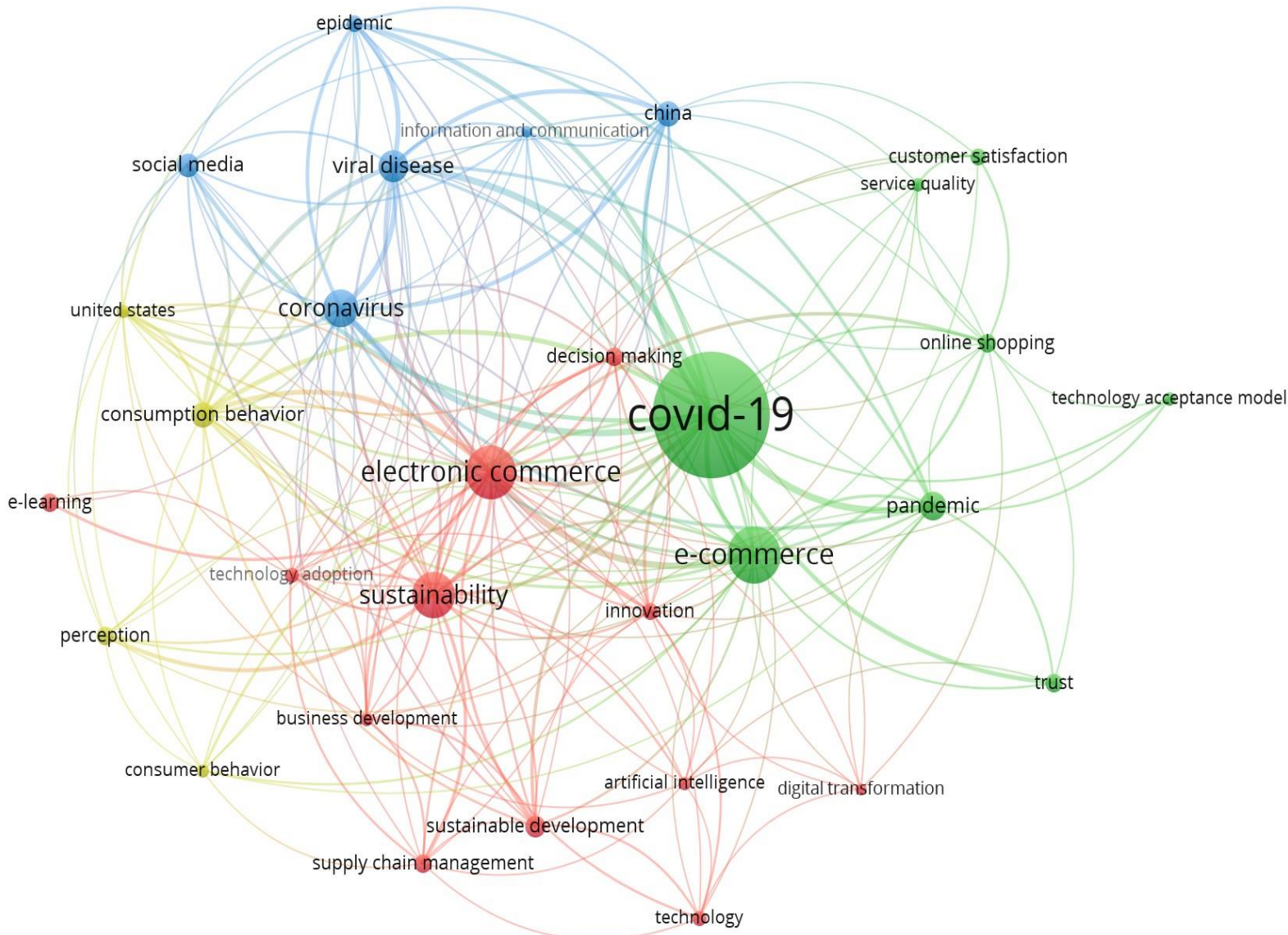

The map shown in Figure 1. shows the closest keywords to "E-Commerce", "Electronic Commerce" and "Covid-19" keywords. Mentioned above, as both "Electronic Commerce" and "E-Commerce" have been used in acadamic literature seperately, both of them have been included to the analysis. The terms which have connection with "E-Commerce", "Electronic Commerce" and "Covid-19" are linked to these words. The thicker link means, the stronger the relation between these two keywords.

As it can seen from the map; there are four clusters. These clusters are grouped according to their relevance to each other via academic studies. Keywords which has been most frequently used together in articles are grouped in the same cluster.

As seen from the Figure 1 map; electronic commerce, sustainability, sustainable development, supply chain management, e-learning, business development, digital transformation, artificial intelligence, innovation, technology, technology adoptation and digital transformation keywords have formed the first and the red cluster. The red cluster can be categorised as sustainability and technology cluster as the most keywords common at this cluster is related with sustainability and technology.

Second cluster has constituted from the keywords of; e-commerce, covid-19, pandemic, trust, technology acceptance model, online shopping, service quality, customer satisfaction. This cluster is shown as the green cluster in the Figure 1 and keywords are commonly about marketing, pandemic and e-commerce.

Third cluster has formed with the keywords of coronavirus, viral disease, social media, epidemic and China as the blue cluster. These keywords can be categorised as virus categorie. 
Fourth and the final cluster includes consumption behavior, perception, consumer behavior and United States keywords, which is the yellow cluster in Figure 1. This cluster can be classified as marketing cluster.

To check the numbers given in Table 1, excluding e-commerce, electronic commerce and covid-19 keywords, sustainability, consumption behavior, China and viral disease are the strongest keywords in terms of either link strength or occurrences.

Sustainability is used in two different meanings in academic literature. One of them is sustainability of the enviroment and green (Jickling, 2000; Deale and Barber, 2012; Koç and Durmaz, 2015) which is named as enviromental sustainability. The other usage is business sustainability and used for the sustainability of corporates (Rhyne, 1998; Van Marrewijk and Werre, 2003; Kiron et al., 2012).

Covid-19 has had a considerable effect on environmental sustainability from both an energy and pollution (Woods, 2021, 40). Covid has also effected sustainability of businesses as numerous entreprenur suffered lots of lose an deven faced bankrupt. Constituting a sustainable business model will be key for entrepreneurs to avoid loses in such unpredictable economic environments. E-Commerce entreprenurs substantially did not face such challenges but establishing a sustainable model for their businesses is also key for their future success and caring about environmental sustainability would definetely increase their brand image. Accordingly sustainability and sustainable development are directly related with the keywords of e-commerce and Covid-19, as proven from the bibliometric analysis.

As the Covid-19 crisis is known to outbreak from Wuhan, China in December, 2019 (Zu et al., $2020,15)$, it is not a surprise that China is among the related keywords. Pandemic and epidemic are also words related to Covid-19. Technology related keywords are also found related to both Covid-19 and e-commerce. E-commerce is the type of trade conducted via technological devices; thus this relation is also reasonable. E-Commerce has been affected by advances in technology as it enables firms to sell products from technological channels (Tran, 2021, 2).

E-commerce was already rapidly growing throughout the recent years. According to EMarketer (2017), global e-commerce will increase \%141 in five years. Covid-19 has increased the pace of this rapid increase and consumers shifted towards e-commerce even more. According to study conducted by Dinesh and Muniraju (2021); \%78,5 respondents have claimed that they shopped online before pandemics; where as this ratio has increased to $\% 92,3$ when they have been asked whether they have shopped online after the pandemics or not (Dinesh and Muniraju, 2021, 126).

Sustainability of the growth of e-commerce has been an issue for marketing and trade literature, which is seen at the red cluster. Green cluster shows that marketing, technology and pandemic are studied together in academic literature. In the pandemic process; the shift towards digital and technological devices both for businesses marketing strategies and consumers' buying decisions can be seen in the green cluster. Yellow cluster have also centered around marketing terms. Finally, blue cluster mainly reunites terms related to covid19 and pandemic.

\section{Conclusion}

Covid-19 has led to the enhancement of digitalisation and thus e-commerce sector (Blakyta and Vardiichyk, 2021, 108). COVID-19 pandemic crisis altered consumption habits of people from all over the world. It will lead to radical social changes not only in the short term period but also in the long term. One of the most important effects of COVID-19 pandemic is the 
digitalization of social and commercial life. In other words, consumers' and businesses will face with a long-term social transformation.

From this perspective, the global importance of e-commerce rises with the Covid-19 pandemics in 2020. Shopping malls and classic stores lose some of their market shares to technology and e-commerce, particularly with the constraints on social life. This year ecommerce increased by 20\% (Davis and Toney, 2020). The e-commerce market has risen 64\% in Turkey over the first six months of 2020 (Turkish Republic Ministry of Commerce, 2020, 2). Mentioned above, from 2019 to 2021 global e-commerce sales have increased dramatically, as much as \%45 (Oberlo, 2021).

It is still not certain this growth is sustainable or not thus sustainability related keywords are found to be common in one of the clusters. Length of the pandemic process is still unknown thus it is hard to predict the future of global trade but it is certain that consumers get more tendency toward e-commerce. Advantages of e-commerce such as easiness, $7 / 24$ access and wide range of product/services might probably continue even after the pandemic process. Thus strategies towards marketing, which is among the clusters of the keyword analysis, would probably aim more digital environment and e-commerce might continue attract businesses even more. Environmental side of sustainability is also important for Covid-19 and E-Commerce businesses since Covid-19 and environmental sustainability had some correlation in terms of energy and pollution. For E-Commerce businesses caring about environmental issues would create a positive brand image and consumers' mind and would most likely increase their market share and revenues.

Covid-19 has effected people's lives in many different ways. As mentioned in this study, most outstanding effect has unfortunately been health. Millions of people lost their lives. Dualistically; trade, marketing and economics related effects has been extremelly striking. Even many businesses suffered from this period, e-commerce has sit in the catbird seat during this period.

Most related keywords related to e-commerce and Covid-19 has been identified in this study and sustainability, marketing related terms and technology related terms have been found to be mostly related towards the relation of e-commerce and Covid-19; which means businesses who care about sustainability of their business and environment, their marketing strategies and succesfully catch-up technological and innovative issues would operate more successfully.

\section{References}

Blakyta, A., \& Vavdiichyk, I. (2021). 10. E-Commerce Market Development Trends. Social and Economic Aspects Of Internet Services Market Development, 100-109.

Chen, W., Liu, W., Geng, Y., Brown, M. T., Gao, C., \& Wu, R. (2017). Recent progress on emergy research: A bibliometric analysis. Renewable and Sustainable Energy Reviews, 73, 10511060.

Chung, L. H. (2015). Impact of pandemic control over airport economics: Reconciling public health with airport business through a streamlined approach in pandemic control. Journal of Air Transport Management, 44, 42-53.

Davis, S., \& Toney, L. (2020). How Coronavirus Is Impacting E-Commerce. https://www.roirevolution.com/blog/2020/06/coronavirus-and-ecommerce/ (Access Date: 03.10.2020).

Deale, C. S., \& Barber, N. (2012). How important is sustainability education to hospitality programs?. Journal of Teaching in Travel \& Tourism, 12(2), 165-187. 
Dinesh, S., \& MuniRaju, Y. (2021). Scalability Of E-Commerce In The Covid-19 Era. International Journal of Research-GRANTHAALAYAH, 9(1), 123-128.

E-Marketer. (2017). The 21th Century Spice Trade, A Guide to Cross-Border E-Commerce Opportunity by DHL.

Euronews. (2020). Google konum verilerine göre Türkiye'de sokağa çıkma yasaklarına ne kadar uyuluyor? https://tr.euronews.com/2020/05/02/google-konum-verilerine-goreturkiye-de-sokaga-cikma-yasaklar-na-ne-kadar-uyuluyor-covid (Access Date: 05.08.2020).

Jickling, B. (2000). A future for sustainability?. Water, air, and soil pollution, 123(1), 467-476.

Kiron, D., Kruschwitz, N., Haanaes, K., \& Velken, I. V. S. (2012). Sustainability nears a tipping point. MIT Sloan Management Review, 53(2), 69.

Koç, S., \& Durmaz, V. (2015). Airport corporate sustainability: an analysis of indicators reported in the sustainability practices. Procedia-social and behavioral sciences, 181, 158-170.

McKinsey \& Company. (2021). Emerging consumer trends in a post COVID 19 world. https://www.mckinsey.com/business-functions/marketing-and-sales/ourinsights/emerging-consumer-trends-in-a-post-covid-19-world (Access Date: 26.10.2021).

Oberlo. (2021). Global E-Commerce Sales (2019-2024). https://www.oberlo.com/statistics/global-ecommerce-sales (Access Date: 02.09.2021).

Rhyne, E. (1998). The yin and yang of microfinance: Reaching the poor and sustainability. MicroBanking Bulletin, 2(1), 6-8.

Song, W., Li, W., \& Geng, S. (2020). Effect of online product reviews on third parties' selling on retail platforms. Electronic Commerce Research and Applications, 39, 100900.

Sun, X. (2021). New E-Commerce Model and Development Strategy of Fresh Food ECommerce Platform Based on ReTech. In E3S Web of Conferences (Vol. 251, p. 01004). EDP Sciences.

Tran, L. T. T. (2021). Managing the effectiveness of e-commerce platforms in a pandemic. Journal of Retailing and Consumer Services, 58, 102287.

Van Eck, N. J., \& Waltman, L. (2021). VOSviewer manual. Leiden: Univeristeit Leiden, 1(1), 154.

Van Marrewijk, M., \& Werre, M. (2003). Multiple levels of corporate sustainability. Journal of Business ethics, 44(2), 107-119.

Van Nunen, K., Li, J., Reniers, G., \& Ponnet, K. (2018). Bibliometric analysis of safety culture research. Safety Science, 108, 248-258.

Wang, M., \& Chai, L. (2018). Three new bibliometric indicators/approaches derived from keyword analysis. Scientometrics, 116(2), 721-750.

Woods, L. (2021). Why environmental sustainability is important. BDJ In Practice, 34(3), 4041.

World Health Organization (WHO). (2020). "Coronavirus disease 2019 (COVID19) Situation Report - 51, https://www.who.int/docs/defaultsource/coronaviruse/situationreports/20200311-sitrep-51-covid19.pdf?sfvrsn=1ba62e57_10. (Access Date: 16.11.2020).

World Health Organization (WHO). (2021) https://covid19.who.int/Access (Access Date: 31.08.2021).

World Trade Organization. (2018). World Trade Statistical Review. https://www.wto.org/english/res_e/statis_e/wts2018_e/wts2018_e.pdf 
Yükselen, C. (2020). Covid-19 Etkisinde "Yeni Pazarlama Normali". https://cemalyukselen.blogspot.com/2020/04/pazarlama.html

Zhang, Y., \& Zhao, Z. (2014). Study on Consumer Behavior Predict in E-commerce Based on Multi-Agent. International Journal of u-and e-Service, Science and Technology, 7(6), 403-412.

Zu, Z. Y., Jiang, M. D., Xu, P. P., Chen, W., Ni, Q. Q., Lu, G. M., \& Zhang, L. J. (2020). Coronavirus disease 2019 (COVID-19): a perspective from China. Radiology, 200490. 